\title{
The $L 2$ acquisition of the partitive pronoun en in French by L1 speakers of German and the role of the $\mathrm{L} 1$
}

Whereas French does have a partitive pronoun (also called quantitative pronoun), standard German does not have one. By means of a Grammaticality Judgment Task it is investigated how advanced German learners of L2 French judge the use of the partitive pronoun or its absence in various contexts. The main goal of the paper is to investigate what role the L1 plays in the acquisition of the use of the partitive pronoun in French. Three different scenarios are explored, namely, the hypotheses i) of poor performance in all contexts, ii) of poor performance only in contexts in which French uses a partitive pronoun, and iii) of poor performance only in contexts where positive transfer from similar constructions in German is not possible. Our results support the third scenario, showing that the possibility of positive transfer should be understood in a broader way. At the same time our results show which contexts are vulnerable and which ones seems to be easier to learn in L2 acquisition of French by German L1 speakers.

\section{Introduction}

The partitive pronoun (also called quantitative pronoun) is a pronoun that is used in combination with an indefinite noun phrase in object position that does not

\footnotetext{
Notes: This paper has benefited from the help and advice of many people. We thank the participants for filling in the tests. We thank the reviewers of this paper for their valuable comments. A special thanks goes to series editor Klaus von Heusinger for his critical remarks and useful suggestions. We are grateful to Thomas Strobel and Elvira Glaser for answering our questions about the use of welch in modern German, to Gabrielle Hess, Liliane Klaey, Thom Westveer, and Richard Zimmerman for their help with the translation of the German test sentences and to Elisabeth Stark for checking the German test. Possible errors are ours. The second author also thanks the URPP Language and Space at the University of Zurich and the Swiss National Science foundation for financial support.
} 
contain an overt noun. ${ }^{1}$ The partitive pronoun can be found both in Romance (e.g. in French, Italian, Catalan as a clitic) and in Germanic languages (e.g. in Dutch, some German dialects).

(1) Ne ho comprato uno.

ITALIAN

PART.CL I.have bought one

'I bought one.'

(2) Ikheb er een gekocht.

DUTCH

I have PART.wK one bought

'I have bought one.'

The Romance partitive pronoun has as its origin the Latin adverbial pronoun inde 'from there', which was lost in several Romance languages, such as Spanish and Portuguese (see, e.g., Badia i Margarit 1947; Martins 2014; Gerards 2020). The partitive pronoun in Dutch and some German dialects derives from the genitive 3rd person plural form iro 'of them, their' (Bech 1952; Philippa, Debrabandere \& Quak 2004). Since the partitive pronoun does not exist in all Romance and Germanic languages, what interests us to know is how the use of the partitive pronoun in a second language is acquired by learners who do not have one in their L1. We will study the acquisition of French as an L2 by native speakers of German.

In French, the partitive pronoun is used in a variety of contexts, such as in combination with a quantifier, as in (3), comparable to (1)-(2), where German does not use a partitive pronoun, as shown in (4).

(3) J'en ai achetéun.

FRENCH

I PART.CL have bought one

'I have bought one.'

1 The labels "partitive pronoun" and "quantitative pronoun" are both misnomers as the examples discussed in the paper show: these pronouns can be used in various contexts which do not necessarily contain a quantity or have a partitive interpretation. In conformance with the title of this volume (Sleeman \& Giusti 2021, this volume), we use the term partitive pronoun in this paper (Sleeman \& Ihsane 2020). See also the introduction to this volume (Giusti \& Sleeman 2021, this volume) for further details on the various types of partitive elements and the terminology used in the volume and Giusti's article in this volume (Giusti 2021, this volume), in which she discusses Italian ne, which is also labelled "quantitative clitic" in the literature. 
(4) Ich habe einen (davon) gekauft.

GERMAN

I have one.M.sG. of.them bought

'I bought one (of them).'

There are also restrictions on the use of the partitive pronoun in other, comparable contexts, for instance in nounless constituents containing a definite article and an adjective (cf. Section 2.1). In such contexts, the partitive pronoun is absent in French, as it is in German. Our main goal is to find out what the role of the L1 is in the learning process when the L1 does not have a partitive pronoun.

The influence of one language on another in situations of language acquisition is called transfer (e.g., Lado 1957; Schwartz \& Sprouse 1994, 1996; Odlin 1989). If the mother tongue has a property also present in the L2, there may be positive transfer, i.e. the mother tongue may help the acquisition of the property in the L2. If the mother tongue does not have a property present in the L2, there may be negative transfer, i.e. it may hinder the acquisition of the property in the L2. Transfer has often been studied in these conditions: wholesale presence or absence of a phenomenon. However, it may also be the case that a phenomenon is absent in both languages in one context but is present in the L2 only in another context: for example, as mentioned above, the partitive pronoun is absent in definite noun phrases containing an adjective both in French and German, but present with a nounless indefinite noun phrase introduced by a quantifier in French, in contrast to German (recall (3) vs. (4)). This raises the question whether there may also be property-by-property transfer depending on the context. Transfer (positive or negative) in the acquisition of a property as a whole and transfer in some contexts only thus represent two different scenarios. A third one is the possibility for cues in an L1 to help the learner to learn in which contexts a phenomenon occurs, despite the absence of this phenomenon in the L1.

In this paper, by means of a Grammaticality Judgment Task submitted to (Swiss) German L1 learners of French L2, these three scenarios will be investigated. ${ }^{2}$ First, does the absence of a partitive pronoun in German L1 lead the L2 learners to perform poorly in all contexts, i.e. with or without a partitive pronoun? Or, second, do the learners perform poorly only on sentences in which L1 speakers of French accept a partitive pronoun, but do they score equally well as the native speakers of French on sentences in which no pronoun is used in both languages? Or, third, do they perform like the French native speakers in all contexts in which there may be positive influence from German in some way, even if German does not have a partitive pronoun? To be able to evaluate the judgments of the L2

2 Our experiment was carried out at the University of Zurich in Switzerland. 
learners on French, we also tested the judgments of a group of native speakers of (Swiss) French by means of the same Grammaticality Judgment Task as the one that was filled in by the L2 learners. In order to evaluate the influence of German L1, we also submitted a Grammaticality Judgment Task in German to the L2 learners, with sentences comparable to the French sentences.

The paper is organized as follows. In Section 2, we present the French partitive pronoun constructions that will be investigated and their German equivalents. In Section 3, we discuss the notion of transfer based on the literature and we present some previous research on the L2 acquisition of the partitive pronoun in relation to the notion of transfer. In Section 4, we will formulate our research question and hypotheses and our methodology. Our results will be presented in Section 5, followed by the discussion in Section 6. Section 7 concludes the paper.

\section{Partitive pronoun constructions in French and their equivalents in German}

In the introduction we showed that the French partitive pronoun en is used in combination with a nounless NP in object position that is introduced by a quantifier. In Section 2.1, we present the other contexts in which en is used. How German behaves in comparable contexts will be shown in Section 2.2.

\subsection{Partitive pronoun constructions in French}

In the introduction, we saw that partitive pronouns may be used in combination with a nounless NP introduced by a quantifier. In French, the partitive pronoun en can also be combined with indefinite noun phrases that are not introduced by a quantifier. The contexts in which en is used are presented and exemplified in Table 1. These contexts are all indefinite nounless noun phrases in object position. We present both the context with a noun and the context with en instead of a noun. ${ }^{3}$

3 In contexts (ii)-(v) it is not possible to simply leave out the noun in the English translation, as in context (i), or to replace it by one, as in context (vi). Therefore, we use the noun in the translation of the contexts with en. This will also be done in context (vii). 
Table 1: Contexts in which en is used.

\begin{tabular}{|c|c|c|}
\hline Context & With a noun & With EN ${ }^{4}$ \\
\hline $\begin{array}{l}\text { (i) NP introduced } \\
\text { by a quantifier }\end{array}$ & $\begin{array}{l}\text { Ils ont lu trois livres. } \\
\text { they have read three books } \\
\text { 'They have read three books.' }\end{array}$ & $\begin{array}{l}\text { Ils en ont lu trois. } \\
\text { they PART.CL have read three } \\
\text { 'They have read three.' }\end{array}$ \\
\hline (ii) Mass NP & $\begin{array}{l}\text { Jean a acheté } d u \quad \text { lait. } \\
\text { Jean has bought PART.DET milk } \\
\text { 'Jean has bought milk.' }\end{array}$ & $\begin{array}{l}\text { Jean en a acheté. } \\
\text { Jean PART.CL has bought } \\
\text { 'Jean has bought milk.' }\end{array}$ \\
\hline (iii) Negated mass NP & $\begin{array}{l}\text { Je ne bois pas de café. } \\
\text { I NEG drink NEG of coffee } \\
\text { 'I do not drink coffee.' }\end{array}$ & $\begin{array}{l}\text { Je n’ en bois pas. } \\
\text { I NEG PART.CL drink NEG } \\
\text { 'I do not drink coffee.' }\end{array}$ \\
\hline $\begin{array}{l}\text { (iv) Non-referential } \\
\text { plural NP }\end{array}$ & $\begin{array}{l}\text { Elle cherche des noix. } \\
\text { she looks.for PART.DET nuts } \\
\text { 'She is looking for nuts.' }\end{array}$ & $\begin{array}{l}\text { Elle en cherche. } \\
\text { She PART.CL looks.for } \\
\text { 'She is looking for nuts.' }\end{array}$ \\
\hline $\begin{array}{l}\text { (v) Negated } \\
\text { indefinite } \\
\text { plural NP }\end{array}$ & $\begin{array}{l}\text { Je ne prends pas de photos. } \\
\text { I NEG take NEG of pictures } \\
\text { 'I do not take pictures.' }\end{array}$ & $\begin{array}{l}\text { Je n’ en prends pas. } \\
\text { I NEG PART.CL take NEG } \\
\text { 'I do not take pictures.' }\end{array}$ \\
\hline $\begin{array}{l}\text { (vi) Indefinite NP } \\
\text { containing an adjective }\end{array}$ & $\begin{array}{l}\text { Il choisit un vélo noir. } \\
\text { he chooses a bike black } \\
\text { 'He chooses a black bike.' }\end{array}$ & $\begin{array}{l}\text { Il en choisit un noir. } \\
\text { he PART.CL chooses a black } \\
\text { 'He chooses a black one.' }\end{array}$ \\
\hline
\end{tabular}

Milner (1978) distinguishes two different interpretations for en in both of the contexts (i) and (vi). He calls these the quantitative and the partitive interpretation, respectively. In the partitive interpretation, the nounless NP is a subset of a delimited superset in the context, see also Berends et al. (2021, this volume):

(5) Deces livres, ils en ont lu trois. of these books they PART.CL have read three 'Of these books, they have read three.'

(6) Deces beaux vélos, il en choisit un noir. of these beautiful bikes he PART.CL chooses a black 'Of these beautiful bikes, he chooses a black one.'

$E n$ has a quantitative interpretation if the elided noun has a kind reading:

4 In the questionnaire that we used in our test, all the test items, including the ones described in Tables 2-4, are introduced by a short situation in parentheses providing an antecedent to the pronoun (see Section 4.2.2). 
(7) Ils voulaient lire des livres; ils en ont lu trois. they wanted to.read PART.DET.PL books they PART.CL have read three 'They wanted to read books; they have read three.'

(8) Il voulait avoir un vélo, il en a choisi un noir. he wanted to.have a bike, he PART.CL has chosen a black 'He wanted to have a bike; he has chosen a black one.'

En cannot be used with any NP in object position. In Table 2 contexts are presented in which en cannot be used. In (vii) the noun phrase is introduced by des, just as in (iv). But whereas in context (iv) with a non-referential NP en can be used, with the referential NP in context (vii), the definite plural pronoun les must be used instead of en (see Ihsane 2013 for a theoretical analysis of the distinction between referential and non-referential noun phrases, supported by the two different types of pronoun). Since en can only be used in combination with indefinite noun phrases, its combination with a definite noun phrase containing an adjective, i.e. context (viii), the definite counterpart of the noun phrase in (vi), is ungrammatical. The definite nounless NP has to be used without en.

Table 2: Contexts in which en cannot be used.

\begin{tabular}{|c|c|c|}
\hline Context & With a noun & With en \\
\hline (vii) Referential plural NP & $\begin{array}{l}\text { Je vois des enfants. } \\
\text { I see PART.DET.PL children } \\
\text { Ce sont Jean et Marie. } \\
\text { These are Jean and Marie } \\
\text { 'I see children. They are Jean } \\
\text { and Marie.' }\end{array}$ & $\begin{array}{l}\text { *J'en vois. } \\
\text { I PART.CL see } \\
\text { ‘I see children.' } \\
\text { Je les vois. } \\
\text { I them see } \\
\text { 'I see them.' }\end{array}$ \\
\hline $\begin{array}{l}\text { (viii) Definite NP containing } \\
\text { an adjective }\end{array}$ & $\begin{array}{l}\text { Il choisit le vélo noir. } \\
\text { he chooses the bike black } \\
\text { 'He chooses the black bike.' }\end{array}$ & $\begin{array}{l}\text { *ll en choisit le noir. } \\
\text { he PART.CL chooses the black } \\
\text { 'He chooses the black one.' } \\
\text { Il choisit le noir. } \\
\text { he chooses the black } \\
\text { 'He chooses the black one.' }\end{array}$ \\
\hline
\end{tabular}

\subsection{Equivalents of the partitive pronoun constructions in German}

Standard German does not have a partitive pronoun comparable to en. Recall that the core function of the partitive pronoun is its use in combination with 
a nounless NP introduced by a quantifier in object position, shown in context (i). As illustrated in (4), in this case German uses a bare quantifier, without the support of a pronoun.

Glaser (1992) observes, however, that since rather recently, standard German uses the pronoun welch in an indefinite interpretation, viz. in an anaphoric function referring to a mass noun or an indefinite plural noun, indicating an unspecified quantity, as in (9) and (10), taken from Glaser (1993): ${ }^{5}$

(9) Wir haben kein Salzmehr, köntest du welches mitnehmen?
we have no salt left could you wELCHES take
'We do not have salt anymore, could you bring salt?'

(10) Wenn sie neue Kartoffeln suchen, wirhaben welche. if you new potatoes look.for we have wELCHE 'If you are looking for new potatoes, we have new potatoes.'

Glaser (1993) observes that in this indefinite-partitive interpretation, welch resembles the French partitive pronoun en or the Italian ne, although the use of welch only partially overlaps with the use of en and ne, viz. only in the indefinite interpretation (i.e. without the specification of a quantity). Welch can however not have a properly partitive interpretation, i.e. specifying a quantified subset, in contrast to en in French, as illustrated in (5). The above discussion implies that welch cannot be used in context (i), since it contains a quantifier, but that it could be used in contexts (ii)-(v) illustrated in Table 1.

Strobel (2017) states that welch cannot be used either in combination with an elliptical noun phrase containing an adjective. ${ }^{6}$ This would mean that it differs from en in that it cannot be used in context (vi), Table 1. It cannot be used in context (viii), Table 2, either, also because this is a definite context. French en cannot be used in this context either, as observed in Section 2.1. ${ }^{7}$

Glaser and Strobel do not discuss the distinction between non-referential (context (iv) in Table 1) and referential (context (vii) in Table 2) indefinite plural NPs.

5 There is no equivalent of welch in English. Therefore, we use a noun in the translation of the examples with welch, including those in Tables 3 and 4.

6 Exemplified by ... könntest du (*welches) gutes kaufen? lit.: could you ( ${ }^{\star}$ WELCHES) good buy? (intended: could you buy good salt?)' referring to Salz in (9) and ... wir haben (*welche) neue 'lit.: we have (*WELCHE) new (intended: we have new potatoes)' referring to Kartoffeln in (10). 7 Glaser (2008) and Strobel (2017) observe that in some German dialects, there are several other variants of the indefinite-partitive pronoun, viz. $(d)(\partial) r(\partial), s(\partial) n$, and $\partial s$, and some innovations: $\emptyset$ and ein-. 
Sleeman \& Ihsane (2020) show that native speakers of German tend to accept welch in non-referential contexts (94\%), but much less so in referential contexts (33\%).

The (indefinite, nounless) contexts in which welch can be used are presented and exemplified in Table 3. Both the context with welch and the preceding context, in the dialogue, with a noun are presented..$^{8,9}$

Table 3: Contexts in which welch can be used.

\begin{tabular}{|c|c|c|}
\hline (ii) Mass NP & $\begin{array}{l}\text { Kind: “Könntest du bitte Brot kaufen?” } \\
\text { 'Child: Could you buy bread, please?' }\end{array}$ & $\begin{array}{l}\text { Mutter: “Nein, wir haben noch } \\
\text { welches.” } \\
\text { 'Mother: No, we still have bread.' }\end{array}$ \\
\hline $\begin{array}{l}\text { (iii) Negated } \\
\text { mass NP }\end{array}$ & $\begin{array}{l}\text { Ann: “Trinken Sie keinen Wein?” } \\
\text { ‘Ann: Don't you drink wine?' }\end{array}$ & $\begin{array}{l}\text { Lucie: “Nein, ich trinke nie } \\
\text { welchen.” } \\
\text { 'Lucie: No, I never drink wine.' }\end{array}$ \\
\hline $\begin{array}{l}\text { (iv) Non- } \\
\text { referential } \\
\text { plural NP }\end{array}$ & $\begin{array}{l}\text { Eric: "Ich sehe Kinder auf dem Schulhof } \\
\text { spielen. Es sind Sara, Paul und Jessica." } \\
\text { 'Eric: I see children playing in the } \\
\text { schoolyard. They are Sara, Paul and } \\
\text { Jessica.' }\end{array}$ & $\begin{array}{l}\text { Sie sagen: "Ich sehe auch welche, } \\
\text { aber ich sehe nicht Sara, Paul und } \\
\text { Jessica." } \\
\text { 'You say: I also see children, but I } \\
\text { do not see Sara, Paul and Jessica.' }\end{array}$ \\
\hline $\begin{array}{l}\text { (v) Negated } \\
\text { indefinite } \\
\text { plural NP }\end{array}$ & $\begin{array}{l}\text { “Liest du niemals Kriminalromane?” } \\
\text { 'Do you never read thrillers?' }\end{array}$ & $\begin{array}{l}\text { “Nein, ich lese nie welche.” } \\
\text { 'No, I never read thrillers.' }\end{array}$ \\
\hline
\end{tabular}

8 A reviewer observes that en in French stands for at least the two constructions below in German (cf. the discussion of (5)):

(i) Peter hat Zucker gekauft.

'Peter has bought sugar.'

Ich habe davon (welchen) genommen.

I have of.it some/a.little taken

'I have taken some from it.'

(ii) Peter sucht Zucker.

'Peter is looking for sugar.'

Ich habe ihm *davon welchen gegeben.

I have to.him of.it some/a.little given

'I have given some to him.'

En may replace a PP containing a delimited discourse familiar set/DP and correspond to davon 'of.it', not to welch 'some/a.little', as in (i); en may also replace a noun or NP and correspond to welch, as in (ii), in which case davon is ungrammatical. We thank the reviewer for this remark and the examples which show that in German davon and welch can co-occur as in (i), unlike the partitive en and the quantitative en in French.

9 In the negative contexts (iii) and (v) we used another type of negation in our German test than in our French test, which will be motivated in Section 4.2.2. 
In Table 4, contexts are presented in which welch cannot be used. We present both the context with a noun and the context without a noun.

Table 4: Contexts in which welch cannot be used.

\begin{tabular}{|c|c|c|}
\hline $\begin{array}{l}\text { (i) NP introduced } \\
\text { by a quantifier }\end{array}$ & $\begin{array}{l}\text { Ich werde einige Museen } \\
\text { besuchen. } \\
\text { 'I will visit some museums.' }\end{array}$ & $\begin{array}{l}\text { Ich werde einige besuchen. } \\
\text { 'I will visit some.' }\end{array}$ \\
\hline $\begin{array}{l}\text { (vi) Indefinite NP } \\
\text { containing an adjective }\end{array}$ & $\begin{array}{l}\text { Tristan hat einen kleinen Bären } \\
\text { im Zoo gesehen. } \\
\text { 'Tristan has seen a little bear in } \\
\text { the zoo.' }\end{array}$ & $\begin{array}{l}\text { Paul hat einen großen im Zoo } \\
\text { gesehen. } \\
\text { 'Paul has seen a big one in } \\
\text { the zoo.' }\end{array}$ \\
\hline (vii) Referential plural NP & $\begin{array}{l}\text { Eric: "Ich sehe Kinder auf dem } \\
\text { Schulhof spielen. Es sind Sara, } \\
\text { Paul und Jessica." } \\
\text { 'Eric: I see children playing in the } \\
\text { schoolyard. They are Sara, Paul } \\
\text { and Jessica.' }\end{array}$ & $\begin{array}{l}\text { Sie sagen: "Ich sehe sie } \\
\text { auch." } \\
\text { 'You say: I also see them.' }\end{array}$ \\
\hline $\begin{array}{l}\text { (viii) Definite NP } \\
\text { containing an adjective }\end{array}$ & $\begin{array}{l}\text { Marie hat im Laden den roten } \\
\text { Ballon gekauft. } \\
\text { 'Marie has bought the red } \\
\text { balloon in the shop.' }\end{array}$ & $\begin{array}{l}\text { Peter hat im Laden den } \\
\text { blauen gekauft. } \\
\text { 'Peter has bought the blue } \\
\text { one in the shop.' }\end{array}$ \\
\hline
\end{tabular}

Strobel (2016), on the basis of an observation made by Glaser (1992), judges the similarity between German welch and French en only a superficial one, because French en is part of a partitive system, whereas modern standard German does not have a comparable partitive system anymore. Although the two systems differ, and welch is not a partitive pronoun as en is, there is a partial overlap with respect to the contexts in which both can be used, namely, contexts (ii)-(v). One of the goals of this paper is to investigate if a kind of transfer from German L1 into French L2 is therefore possible. In the next section we discuss the notion of transfer.

\section{Transfer and the role of transfer in the acquisition of the partitive pronoun}

The notion of transfer has been used since Lado (1957), in a behaviorist context, and is still one of the major concepts of second language acquisition. To be able to investigate if there could be transfer from L1 German in the case of the acquisition of the partitive pronoun in L2 French, we first discuss the notion of transfer in 
Section 3.1. In Section 3.2, we present previous studies that also investigate the L2 acquisition of the partitive pronoun in relation to transfer from the $\mathrm{L}^{10}$

\subsection{Transfer}

Odlin (1989) defines the notion of transfer as follows:

Transfer is the influence resulting from the similarities and differences between the target language and any other language that has been previously (and perhaps imperfectly) acquired. (Odlin 1989: 27)

According to this definition transfer can be positive (if there are similarities between the languages) or negative (if the languages differ). Furthermore, the definition suggests that there can be transfer from the L1 onto the L2, but also, e.g., from the L2 onto the L3.

Although in the behaviorist view the notion of transfer played an important role, in later theories this was not always the case. A very influential theoretical view in the generative perspective is Schwartz \& Sprouse $(1994,1996)$. Their Full Access/Full Transfer theory states that the initial state of L2 acquisition is the final state of $\mathrm{L} 1$ acquisition, which is transferred onto the L2. Thanks to full access to Universal Grammar (UG), the L2 learner is capable of resetting the parameters set for the L1 into the values of the L2. According to Pienemann, Di Biase, Kawaguchi \& Håkansson (2005), however, there can only be transfer from the L1 if an L1 structure can be parsed by the L2 learner, which means that the L2 learner has to be rather advanced. On this view, the final state of the L1 is not necessarily the initial state of the L2. Besides research on L2 acquisition, some of which we will discuss below, research on L3 acquisition has shown that in the initial state of L3 acquisition there is predominantly transfer from the L1 (Na Ranong \& Leung 2009; Jin 2009; Hermas 2010; Stadt, Hulk \& Sleeman 2018), although it becomes less influential in later stages of the learning process. Therefore, in this paper, we start from the assumption that transfer does play a role from the start of L2 acquisition and may continue to play a role. What interests us is what exactly can be transferred. We present three scenarios.

(A) In studies of transfer, what is often studied is transfer of a linguistic phenomenon, or, in UG research, the resetting of a parameter. Japanese, for instance, does not have articles. Therefore, it is predicted that Japanese learners of

10 Besides the notion "transfer", the notion of cross-linguistic influence has been used in the literature. In this paper we use the former concept. 
English as an L2 will leave out the article in cases where it is used in English and will not be able to make a distinction between definite and indefinite articles (Zobl 1984), at least in the initial stages of L2 acquisition. If an L1 does not have null subjects, such as English, it is predicted that, at least in the initial stages, but possibly also still at a near-native level, the L2 learners will use an overt pronoun in cases where a null pronoun is used in the L1, such as in topic continuity contexts in Spanish (see, e.g., Montrul \& Rodrígues Louro 2006) or Italian (see, e.g., Belletti, Bennati \& Sorace 2007). Rothman (2007) reports an underproduction of overt subjects in Spanish L2 in contrastive contexts, which suggests that the L1 English learners leave out the pronoun in L2 Spanish where they use it in English. Rothman attributes the overuse of overt subjects in other studies and the underproduction of overt subjects in his study to L2 insensitivity to discourse-pragmatic constraints concerning null subjects. This knowledge is missing in English, which is not a null subject language. Therefore, transfer is not possible.

(B) Zobl (1984) noted that the L2 acquisition of articles in English is delayed if the L1 does not have them, which means that there is an underproduction of articles in contexts where they should be used, as a result of negative transfer. There are also contexts, however, in which English does not use an article. These are, e.g., indefinite mass nouns or proper names. Will Japanese or Chinese learners of L2 English be more accurate on the omission of the article in contexts where no article is required than in contexts where it is required? This is what was found by Master (1987).

(C) A third point with respect to the question "what may be transferred?" is if learners may rely on other cues in their language, which may help them to learn a distinction. Japanese does not have articles, but it does have demonstrative pre-modifiers. May deictic prenominal modifiers expressed by sono 'that' (Fukui 1995) help the L2 learner to learn the definite-indefinite distinction in English? This is suggested, a.o., by Kaku (2006). Just like English, Dutch does not have null subjects. Van Kampen \& Pinto (2007) show, however, that in Dutch a distinction is made between weak pronouns and demonstrative pronouns corresponding to the null subject versus overt subject pronoun distinction in Italian. Pinto (2018) suggests that this indirect knowledge may help the Dutch learner to make the distinction in Italian L2. 


\subsection{The role of transfer in the $L 2$ acquisition of the partitive pronoun}

The research that has been done on the L2 acquisition of the partitive pronoun in French is, to the best of our knowledge, limited.

Wust (2009), using a dictogloss task, shows that in her study not a single low or intermediate L1 English learner of French as an L2 used the partitive pronoun, suggesting that it is acquired late by speakers of English, which does not have a partitive pronoun.

Sleeman \& Ihsane (2017) used a Grammaticality Judgment Task to test the knowledge of the use of the partitive pronoun (called 'quantitative pronoun' in this work) in French of Dutch Bachelor and Master students, studying French at university level. ${ }^{11}$ Their test contained various contexts, comparable to the contexts (i)-(viii) presented in Section 2.1. In contrast to English and German, Dutch does possess a partitive pronoun, more commonly called 'quantitative pronoun' in the literature on Dutch (Berends et al., 2021, this volume), as illustrated in (2), although, in standard Dutch, it can only be used in context (i). One of Sleeman \& Ihsane's aims was to investigate if, even at an advanced level of study, there is positive transfer in contexts where the partitive pronoun is present or absent both in Dutch and in French or negative transfer in contexts in which the use of the partitive pronoun differs, as in scenario B presented in Section 3.1. For this goal they submitted a French and a Dutch version of the Grammaticality Judgment Task to the students. In their results they found support for the hypothesis that there is negative transfer in cases in which the use of the partitive pronoun in Dutch and in French differs: in all contexts the L2 French results differed significantly from the L1 Dutch results. They found partial support for the hypothesis that there is positive transfer in cases in which the use of the partitive pronoun in Dutch and in French does not differ, although the support becomes more evident if the results of the two groups of L2 learners are separated: the Master students were more positively influenced by the L1 than the Bachelor students.

While Dutch has a partitive pronoun, German does not have one. In the present paper we investigate the L2 acquisition of the use of the partitive pronoun in French by L1 German learners.

11 Before starting their study of French at university, the students had already learned French during six years in secondary education, where they reached the B1/B2 level of the Common European Framework of Reference. 


\section{Research question, hypotheses and methodology}

The discussion of the notion of transfer in Section 3.1 leads to three alternative hypotheses, which we present in Section 4.1. The methodology that we used for this paper follows in Section 4.2.

\subsection{Research question and hypotheses}

The goal of this paper is to investigate how L1 speakers of a language that does not have a partitive pronoun, in this case German, acquire the use of the partitive pronoun in L2 French. We are particularly interested in the role of transfer. Our Research Question is therefore: what is the role of transfer in the L2 acquisition of the partitive pronoun in French by learners who do not have a partitive pronoun in their L1, German? Based on the discussion of the notion of transfer in Section 3.1, we formulate three alternative hypotheses in this section.

In Section 3.1 we discussed the L2 acquisition of null subjects by learners who do not have a null subject in their L1. We mentioned that according to Rothman (2007) overproduction or underproduction of overt subjects in the L2 may be due to the absence of relevant discourse-pragmatic distinctions in the L1. This means that in scenario A presented in Section 3.1 transfer is not possible. Since German does not have a partitive pronoun, whereas French has one, this leads to hypothesis 1 :

Hypothesis 1: L2 learners of French with German as their L1 will differ significantly from L1 speakers of French both in contexts where the partitive pronoun is required in French and in contexts where the partitive pronoun is not used in French or they will perform at chance.

Under scenario B presented in Section 3.1, there is negative transfer, but also positive transfer in other contexts. For the acquisition of the partitive pronoun, this can be formulated as hypothesis 2:

Hypothesis 2: L2 learners of French with German as their L1 will differ significantly from L1 speakers of French in contexts where the partitive pronoun is required in French, but not in contexts where the partitive pronoun is not used in French. 
In Section 3.1 we also discussed the possibility of getting positive influence from the L1 if the L1 does not have a phenomenon but makes the relevant distinctions for the acquisition of the phenomenon in the L2 in another way. Hypothesis 3 is based on scenario $\mathrm{C}$ :

Hypothesis 3: In contexts in which L1 German and L1 French have similar constructions, there may be positive influence from the L1 German. In contexts in which the two languages differ, there may be negative influence.

Similar contexts are contexts where German uses welch and French en (contexts (ii)-(v) in Tables 1 and 3), contexts where a definite pronoun is used (context (vii) in Tables 2 and 4) and where no pronoun, that is $\emptyset$, is used (context (viii) in Tables 2 and 4). Contexts in which the two languages differ are context (i) with a quantifier and context (vi) with an indefinite determiner and an adjective (see Tables 1 and 4).

This is an exploratory study. We have formulated three alternative hypotheses, and we will evaluate them in the light of our results.

\subsection{Methodology}

\subsubsection{Participants}

We tested 33 native speakers of German studying French as their L2 at the University of Zurich in Switzerland. They were all doing their second semester at university and had studied French for eight years on average in secondary education. ${ }^{12}$ The expected proficiency in French of the students when they reach university in Zurich corresponds to the level B2 of the Common European Framework of Reference for Languages. 14 participants were left out for different reasons, for instance because they were bilingual French-German, had lived in a French speaking area for a long period, or had not fully completed the questionnaire. Our study therefore includes 19 L1 German students learning French as their L2 (age range: 18-29). 17 indicated that their mother tongue is Swiss German (dialect), and two did not give any information about the variety of German they speak. All

12 The classical training before university comprises 8-9 years of French (secondary school and high school). There were 4 students who reported having studied French for fewer years ( 2 students studied French for 7 years, 1 for 5,5 years and one for 4,5 years). 
participants gave their informed consent for the analysis of their anonymous data by the authors of this paper for scientific purposes.

To be able to evaluate the judgments of the L2 learners of French, we also tested 18 native speakers of French, from different areas of Switzerland, but also a few residents of the Netherlands.

\subsubsection{Questionnaire}

The questionnaire used for the present study was a Grammaticality Judgment Task (GJT) comprising three parts: Part 1 with French test items, Part 2 with German test items and Part 3 with questions on the students' background (age, sex, mother tongue(s), language level and certificates). Part 1 was the questionnaire used in Sleeman \& Ihsane (2017), a study of the knowledge of the use of en by Dutch L1 advanced learners of French. Part 2 was a slightly modified version of the German questionnaire used in Sleeman \& Ihsane (2020) to test whether partitivity can be (partially) expressed in German in the same way as in French and Dutch despite the absence of a partitive pronoun in German. This German questionnaire was itself slightly adapted from the Dutch questionnaire created for our study in Sleeman \& Ihsane (2017).

In our GJT, the participants had to choose between two options: "correct" and "incorrect", reflecting their judgments. We opted for a binary-choice task because the test was long: ${ }^{13}$ the questionnaire filled in by the L1 German speakers for this study comprised 92 French test items, including 8 fillers, and 83 German test items, including 15 fillers, plus a short questionnaire on their background. Before starting the test, the participants were asked to read a short introductory passage explaining that, although it could be a simplification, they would have to choose between two answers ("correct/incorrect") and that, for each test item, they should choose the option closest to their judgement. To avoid ambiguity, a brief context was provided in brackets for some test items, as shown in the example below:

(11) [Sophie: «Tu ne veux pas de salade?»]-Paul: «Non, je n' en veux pas." you NEG want NEG of salad no I NEG PART.CL want NEG 'Don't you want any salad?' 'No, I don't want any.'

[Context : En désignant un saladier au milieu de la table.]

13 Different studies such as Bader \& Häussler (2010) and Weskott \& Fanselow (2011) report that gradient and binary judgments yield quite similar results. 
'Context: Designating a salad bowl in the middle of the table.'

Markiere nur eine Option:

'mark only one option'

- Richtig

'correct'

- Nicht richtig

'not correct'

There were several variants of the test items in the questionnaire, with different targets. In a variant of example (11) above, for instance, the students had to evaluate a sentence with a definite pronoun as in (12), which is incorrect in the given context. For (12), the context and the information in square brackets were the same as in (11).

(12) Non, je ne la veux pas.

no I NEG it want NEG

'No, I don't want it'.

The participants thus had to judge both grammatical and ungrammatical sentences, according to our judgments. They took the test in class as an offline task and had until the end of the class to complete it, i.e. 45 minutes at most.

The German test items were generally comparable to the French ones. However, since German does not have a counterpart of en, some of the test items did not contain a corresponding overt element. This was the case of context (i) with a quantifier and context (vi) with an indefinite article and an adjective (see Table 4). Otherwise, we used welch in the constructions in which we expected this element to be accepted (see Table 3), that is, contexts (ii)-(v): mass NPs, negated NPs (singular and plural) and non-referential plural indefinites. The variants of the test items with welch contained a definite pronoun as in (12) above. For context (vii) with a referential plural indefinite, we used the expected definite pronoun in the examples but also tested the acceptance of welch. Furthermore, in all the contexts in which we tested welch, i.e. (ii)-(v) and (vii), we added a third option, the use of an NP instead of a pronoun, as in (13), which is possible in German (and in Dutch from which the German questionnaire was adapted) and which will not be part of the analysis.

(13) [Context: Isabelle:

Haben Sie sich Zucker von Ihrem Nachbarn geliehen?] have you yourself sugar of your neighbour borrowed 'Did you borrow sugar from your neighbour?' 
Mélanie: Ja, er hat mir Zucker geliehen.

yes he has me sugar lent

'Yes, he has lent me sugar.'

For each negative context (singular and plural), we also added two test items with a negative determiner kein 'no' as in (14), but which will not be part of the analysis. Welch does not combine with the negation nicht 'not', but kein is used instead. In our questionnaire, we used nie 'never' as a negation because nicht welch 'not welch' is ungrammatical.

(14) [Context: Louis: Haben sie kein Geld?]

have you no money

'Don't you have money?'

Sara: Nein, ich habe keins.

no I have none

'No, I don't have any.'

As for context (viii), with a definite article and an adjective, the German test items did not contain a pronoun, on a par with the French ones.

The questionnaire also contained test items for the distinction between a quantitative and a partitive interpretation, which will not be analyzed here (but see Sleeman \& Ihsane 2017 for French and Sleeman \& Ihsane 2020 for German).

Of the questionnaire we used the following test items for the analysis: ${ }^{14}$

(i) Quantif 3 test items (with Ø)

(ii) Mass 6 test items (3 with welch; 3 with a definite pronoun)

(iii) Neg sg 6 test items (3 with welch; 3 with a definite pronoun)

(iv) Non-ref 6 test items (3 with welch; 3 with a definite pronoun)

(v) Neg pl 6 test items (3 with welch; 3 with a definite pronoun)

(vi) Indef + adj 3 test items (with Ø)

(vii) Refer 6 test items (3 with welch; 3 with a definite pronoun)

(viii) Def + adj 3 test items (with $\emptyset$ )

As for the native speakers of French, they filled in the French part of the Grammaticality Judgment Task taken by the L1 German participants, that is, the

14 In the next sections, we will at times use the following short labels to refer to the eight contexts described in Section 2.1: (i) quantif, (ii) mass, (iii) neg sg, (iv) non-ref, (v) neg pl, (vi) indef + adj, (vii) refer, and (viii) def + adj. 
same 92 questions. Some of the native speakers of French took the test as an online task. ${ }^{15}$

We calculated the percentages of acceptance for the test items that we presented in Section 2 as correct and for the test items that we presented as incorrect. However, for the German part, we had no incorrect sentences for the contexts in which German does not have an overt counterpart to en, namely contexts (i) with a quantifier, (vi) with an indefinite article + adjective, and (viii) with a definite article + adjective.

\section{Results}

To understand the role of the L1 in the acquisition of the uses of en in French, we compared the percentages of acceptance for i) French L1 versus German L1, ii) French L1 versus French L2, and iii) French L2 versus German L1. Examining French L1 versus German L1 allowed us to see how native speakers react in the eight contexts under study and to identify any difference. The comparison between French L1 and French L2 enabled us to test our three hypotheses. Finally, we compared French L2 and German L1 to determine the influence of German L1 on French L2 and to further check our Hypothesis 3. For the first two comparisons, i) and ii), we performed a Mann-Whitney U test, whereas for comparison iii) we performed a Wilcoxon test. The results are reported in the figures presented in the following subsections.

\subsection{French L1 and German L1}

First, we present the results of the native speakers. Figure 1 represents the correct sentences and Figure 2 the incorrect sentences. In Figure 1, we left out contexts (i) with a quantifier and (vi) with an indefinite article + adjective because the French test items and the German ones are not directly comparable since German does not have a counterpart to en in these contexts. In Figure 2, we left out the contexts for which we had no ungrammatical test items in German, i.e. contexts (i) with

15 Our questionnaire contained some more contexts than contexts (i)-(viii). For this study, we only analyzed contexts (i)-(viii), but not with an NP or kein. For German, there was no ungrammatical variant of contexts (i), (vi) and (viii). For French we analyzed the judgments on 48 sentences and for German the judgments on 39 sentences. 
a quantifier, (vi) with an indefinite article + adjective, and (viii) with a definite article + adjective.

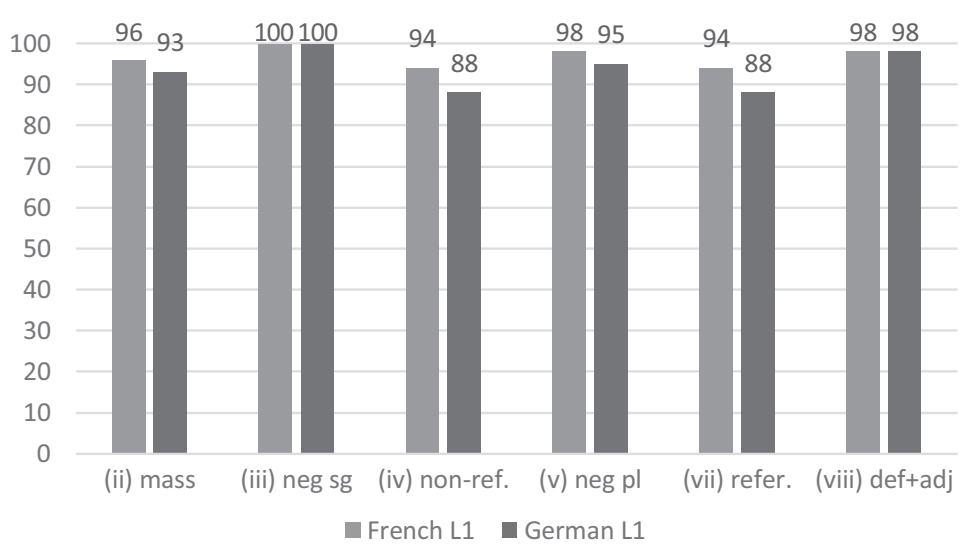

Figure 1: French L1 versus German L1, correct sentences.

Overall, Figure 1 shows that all the native speakers scored as expected in the contexts illustrated in at least $88 \%$ of the cases. More precisely, the French L1 accepted en in at least $94 \%$ of the cases in contexts (ii)-(v) and rejected it in contexts (vii) and (viii) (see also Fig. 2); in context (vii) with referential plural indefinites, they accepted the definite pronoun in $94 \%$ of the cases and in context (viii) with a definite article + adjective, they accepted the absence of en in 98\% of the cases. In addition, French L1 accepted en in 100\% of the cases in context (i) with a quantifier and in $98 \%$ of the cases in context (vi) with an indefinite article + adjective, not included in Figure 1. The German L1 accepted welch in at least $88 \%$ of the cases in contexts (ii)-(v) and the definite pronoun in $88 \%$ of the cases in context (vii) with a referential plural indefinite. In context (viii), with a definite article + adjective, the test items without a pronoun were accepted in $98 \%$ of the cases. In addition, German L1 accepted "quantifier $+\emptyset$ " (context i) in $79 \%$ of the cases, and "indefinite article + adjective $+\emptyset$ " (context vi) in $86 \%$ of the cases, not included in Figure 1.

These results seem to confirm the description in Section 2.2, namely, that welch is possible in contexts (ii)-(v). The fact that welch was not accepted in context (vii), with referential plural indefinites (see also Fig. 2), suggests that the relevant distinction in the acceptance or non-acceptance of welch is the notion of referentiality: indeed, all the contexts in which welch was accepted are non-referential, like the ones in which en is used (Ihsane 2013 for French). This supports the conclusions in Sleeman \& Ihsane (2020) where we proposed that welch replaces non-referential 
constituents, labelled -Ref(erentiality) Phrase, but not referential ones, labelled + Ref(erentiality) Phrase.

Let us now turn to Figure 2, for incorrect sentences. We first report the results of the native speakers of French, and then, the ones of the native speakers of German.

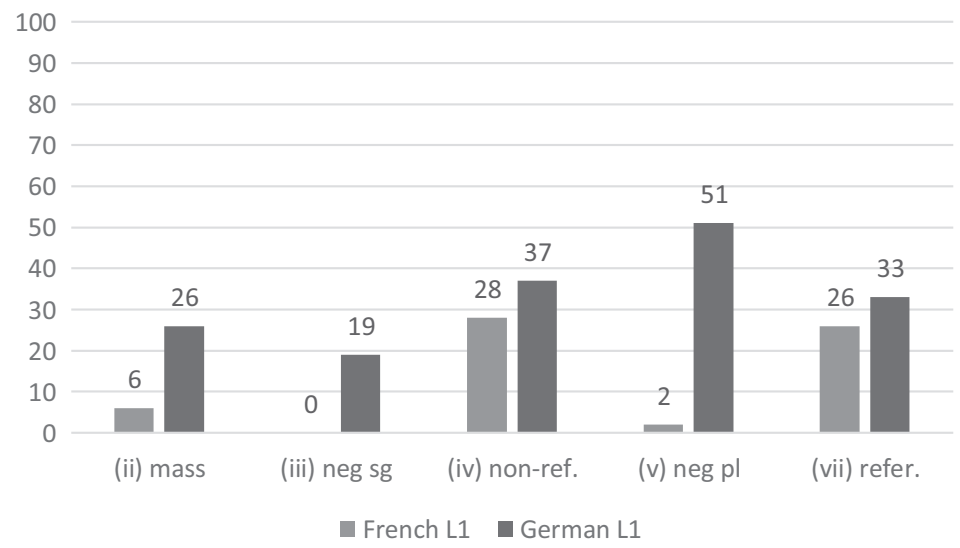

Figure 2: French L1 versus German L1, incorrect sentences.

In the incorrect sentences, the definite pronoun was accepted by the French L1 in $6 \%$ of the cases in context (ii) with a mass noun, in $0 \%$ of the cases in context (iii) with a negated singular indefinite and in $2 \%$ of the cases in context (v) with a negated plural indefinite, as expected. In addition, the omission of en was never accepted in context (i), with a quantifier, and en was always rejected in context (viii), with a definite article + adjective, two constructions not included in Figure 2, since German does not have an overt counterpart to en. The results for context (iv), with non-referential plural indefinites, and context (vii), with referential plural indefinites, are not as sharp: French L1 speakers accepted the definite pronoun in $28 \%$ of the cases and en in $26 \%$ of the cases, respectively. This shows that the notion of referentiality is difficult for native speakers of French, and especially confusing in incorrect sentences. As for context (vi), which is not included in the figure, with an indefinite article + adjective, it seems that for some speakers these constructions are acceptable without the pronoun en (28\% of acceptance). This may be the influence of oral French, where the omission of en is more accepted.

The results for the German L1 speakers are more contrasted. The speakers accepted the definite pronoun in $26 \%, 19 \%, 37 \%$, and $51 \%$ of the cases in different contexts, namely contexts (ii) with a mass noun, (iii) with a negated singular indefinite, (iv) with a non-referential plural indefinite and (v) with a 
negated plural indefinite, respectively. Furthermore, they accepted welch in 33\% of the cases in context (vii), with a referential plural indefinite, which shows that the notion of referentiality is difficult for native speakers of German as well, especially in the incorrect sentences. ${ }^{16}$ It may also be the case that the test items for these contexts were not sufficiently clear or that the participants did not pay enough attention to the information in brackets whose purpose was precisely to avoid any confusion. For the remaining constructions, i.e. (i) with a quantifier, (vi) with an indefinite article + adjective, and (viii) with a definite article + adjective, we did not have any incorrect test items for German.

A statistical analysis of the comparison between French L1 and German L1 is provided in Table $5 .^{17}$

Table 5: Comparison of acceptance French L1 and German L1.

\begin{tabular}{lrrrrrrrr}
\hline & \multicolumn{7}{c}{ correct } & \multicolumn{7}{c}{ incorrect } \\
& $\begin{array}{l}\text { French } \\
\text { L1 }\end{array}$ & $\begin{array}{l}\text { German } \\
\text { L1 }\end{array}$ & U-score & p-value & $\begin{array}{l}\text { French } \\
\text { L1 }\end{array}$ & $\begin{array}{l}\text { German } \\
\text { L1 }\end{array}$ & U-score & p-value \\
\hline (ii) mass & $96 \%$ & $93 \%$ & 162 & 0,645 & $6 \%$ & $26 \%$ & 87 & 0,003 \\
\hline (iii) neg sg & $100 \%$ & $100 \%$ & 171 & 1,000 & $0 \%$ & $19 \%$ & 117 & 0,011 \\
\hline (iv) non-ref. & $94 \%$ & $88 \%$ & 151,5 & 0,409 & $28 \%$ & $37 \%$ & 141,5 & 0,339 \\
\hline (v) neg pl & $98 \%$ & $95 \%$ & 153,5 & 0,323 & $2 \%$ & $51 \%$ & 23,5 & $<0,001$ \\
\hline (vii) refer. & $94 \%$ & $88 \%$ & 144 & 0,272 & $26 \%$ & $33 \%$ & 153 & 0,561 \\
\hline (viii) def adj & $98 \%$ & $98 \%$ & 170,5 & 0,969 & $0 \%$ & & & \\
\hline
\end{tabular}

The comparison between the results of the native speakers of French and those of the native speakers of German shows that, for the correct sentences, there are no significant differences.

Comparing French L1 and German L1 on the incorrect sentences, we can observe that there are three contexts with significant differences: contexts (ii) with a mass noun, (iii) with a negated singular indefinite, and (v) with a negated

16 According to a reviewer, this could be because an existential inference can always be made from a definite expression. Indeed, in Sleeman \& Ihsane (2020: 795), we observe that some native speakers of German accept welch with referential noun phrases, as in the filler below:

(i) [Sophie sieht die Kinder spielen.] - Sophie sieht welche spielen.

'[Sophie sees the children playing.] - Sophie sees children play.'

17 In our tables, the terms correct and incorrect indicate our expectations. However, as the results for context (v) with negative plurals, for instance, show (i.e. 51\%), our expectations were not always met. 
plural indefinite. For the contexts with non-referential plural indefinites (iv) and with referential indefinites (vii), there are no significant differences between French L1 and German L1.

\subsection{French L1 and French L2}

The next figures illustrate the comparison between French L1 and French L2. The results for the correct sentences are illustrated in Figure 3 and the ones for incorrect sentences in Figure 4.

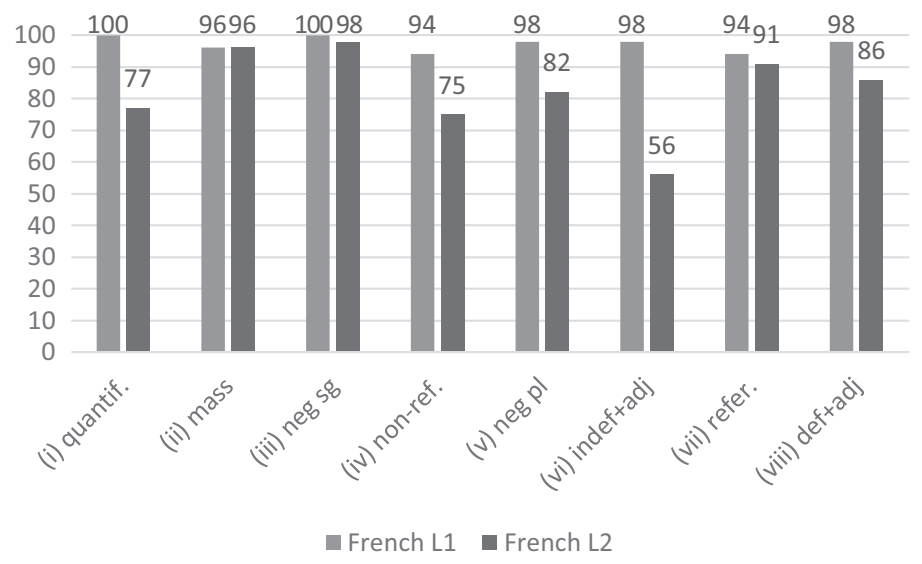

Figure 3: French L1 versus French L2, correct sentences.

The results for French L1, both in correct and incorrect sentences, have been discussed in relation to Figures 1 and 2. For French L2, we can observe that for contexts (ii) with a mass noun, (iii) with a negated singular indefinite, (v) with a negated plural indefinite, (vii) with a referential plural indefinite and (viii) with a definite article + adjective, the correct test items were accepted in at least $82 \%$ of the cases. This means that en was accepted by the learners in contexts (ii), (iii) and (v), that the definite pronoun was accepted in context (vii) and that the sentences without a pronoun were accepted in (viii). For the other contexts, the percentages were slightly lower: en was accepted in 77\% of the cases in context (i) with a quantifier, in $75 \%$ of the cases in context (iv) with a non-referential plural indefinite and in $56 \%$ of the cases in context (vi) with an indefinite article + adjective.

The results for the incorrect sentences are presented in Figure 4. 


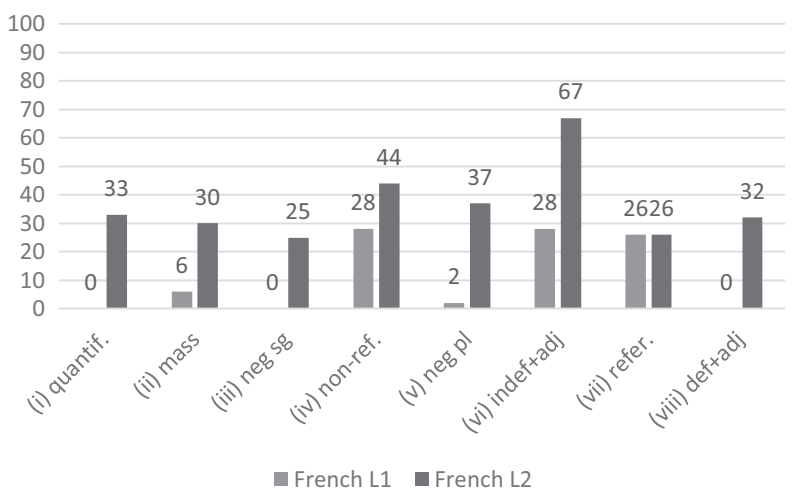

Figure 4: French L1 versus French L2, incorrect sentences.

As Figure 4 shows, all the incorrect sentences are accepted by the learners in at least $25 \%$ of the cases. For most contexts, the percentages are between $25 \%$ and 37\%; however, for contexts (iv) with a non-referential plural indefinite and (vi) with an indefinite article + adjective, the percentages are higher: $44 \%$ and $67 \%$, respectively. The fact that the participants are first year Bachelor students may explain these results. Furthermore, ungrammatical items are generally more difficult to identify and to evaluate compared to grammatical ones. Although the learners are more uncertain with incorrect sentences, this also holds for the L1 speakers of French, who accept incorrect sentences in 26-28\% of the cases in three contexts, (iv) with a non-referential plural indefinite, (vi) with an indefinite article + adjective and (vii) with a referential plural indefinite.

Table 6 provides the statistical analysis of the comparison between the results for French L1 and French L2.

Table 6: Comparison of acceptance French L1 and French L2.

\begin{tabular}{lrrrrrrrrr}
\hline & correct & \multicolumn{7}{c}{ incorrect } \\
\hline & $\begin{array}{l}\text { French } \\
\text { L1 }\end{array}$ & $\begin{array}{l}\text { French } \\
\text { L2 }\end{array}$ & U-score & p-value & $\begin{array}{l}\text { French } \\
\text { L1 }\end{array}$ & $\begin{array}{l}\text { French } \\
\text { L2 }\end{array}$ & U-score & p-value \\
\hline (i) quantif & $100 \%$ & $77 \%$ & 72 & $<0,001$ & $0 \%$ & $33 \%$ & 36 & $<0,001$ \\
\hline (ii) mass & $96 \%$ & $96 \%$ & 170 & 0,955 & $6 \%$ & $30 \%$ & 87 & 0,003 \\
\hline (iii) neg sg & $100 \%$ & $98 \%$ & 162 & 0,330 & $0 \%$ & $25 \%$ & 99 & 0,002 \\
\hline (iv) non-ref. & $94 \%$ & $75 \%$ & 114 & 0,035 & $28 \%$ & $44 \%$ & 125 & 0,122 \\
\hline (v) neg pl & $98 \%$ & $82 \%$ & 134,5 & 0,084 & $2 \%$ & $37 \%$ & 69,5 & $<0,001$ \\
\hline (vi) indef + adj & $98 \%$ & $56 \%$ & 68,5 & $<0,001$ & $28 \%$ & $67 \%$ & 72,5 & 0,002 \\
\hline (vii) refer. & $94 \%$ & $91 \%$ & 154 & 0,482 & $26 \%$ & $26 \%$ & 169 & 0,948 \\
\hline (viii) def + adj & $98 \%$ & $86 \%$ & 125,5 & 0,043 & $0 \%$ & $32 \%$ & 90 & 0,001 \\
\hline
\end{tabular}


As for the correct sentences, the comparison between French L1 and French L2 shows significantly different results for contexts (i) with a quantifier and (vi) with an indefinite article + adjective. In addition, there are two results that are less clearly significant: for context (iv) with non-referential plural indefinites and context (viii) with a definite article + adjective. In contexts (ii), (iii), (v) and (vii), there are no significant differences. How these results can be interpreted is discussed in Section 6.

For the incorrect sentences, significant differences between French L1 and French L2 can be observed in all contexts except (iv) and (vii): with non-referential indefinites and with referential indefinites. This confirms our earlier remark in relation to Figures 1 and 2 and suggests that the difference between these contexts is not clear for both the native speakers of French and the learners, especially in incorrect sentences.

\subsection{French L2 and German L1}

Finally, let us consider the comparison between French L2 and German L1, starting with the results for correct sentences (Figure 5), before turning to the results for incorrect sentences (Figure 6). In Figure 5, as in Figure 1, contexts (i) and (vi) were left out and in Figure 6, as in Figure 2, contexts (i), (vi) and (viii) were left out for the reasons explained earlier (i.e. dubious comparison and absence of data, respectively).

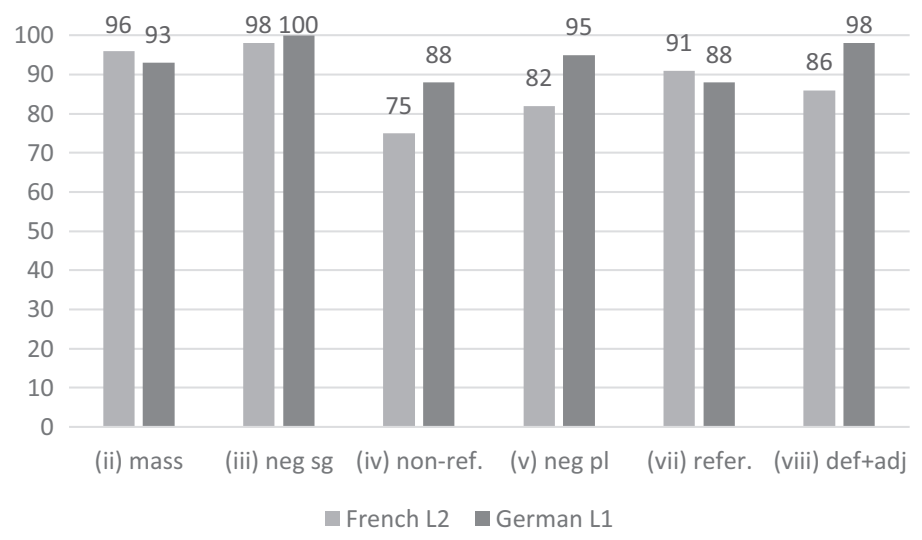

Figure 5: French L2 versus German L1, correct sentences.

The results for French L2, for correct and incorrect sentences, have been discussed in relation to Figures 3 and 4, and the ones for German L1 in relation to Figures 1 and 2. Figure 5 shows that learners accept the sentences both in German L1 and 
in French L2 in at least $82 \%$ of the cases. There is one percentage that is slightly lower, though: for French L2 in context (iv) with non-referential plural indefinites, it is $75 \%$.

Let us now turn to the incorrect sentences, presented in Figure 6.

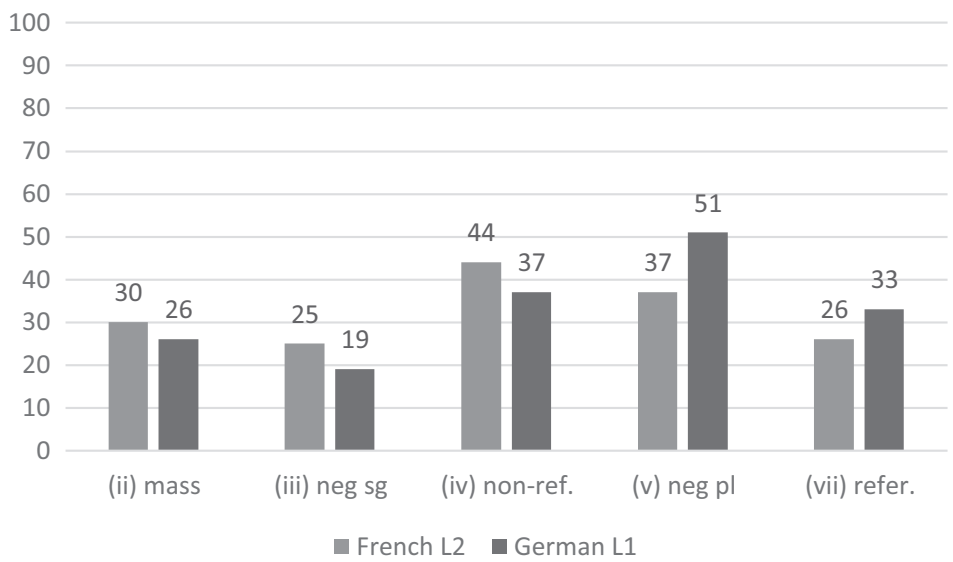

Figure 6: French L2 versus German L1, incorrect sentences.

As can be observed in Figure 6, the percentages of acceptance vary between 25\% and 44\% for French L2 and between 19\% and 51\% for German L1. This means that in both varieties the participants accept, to some extent, the definite pronoun in contexts where it is not expected, i.e. (ii), (iii), (iv) and (v). Furthermore, where the definite pronoun is expected, i.e. in context (vii), en is accepted in French L2 and welch is accepted in German L1, to some extent.

The statistical analysis of the comparison between German L1 and French L2 is reported in Table 7.

Table 7: Comparison of acceptance French L2 and German L1.

\begin{tabular}{lcrrrrrrrr}
\hline & correct & \multicolumn{7}{c}{ incorrect } \\
& $\begin{array}{l}\text { French } \\
\text { L2 }\end{array}$ & $\begin{array}{l}\text { German } \\
\text { L1 }\end{array}$ & Z-score & p-value & $\begin{array}{l}\text { French } \\
\text { L2 }\end{array}$ & $\begin{array}{l}\text { German } \\
\text { L1 }\end{array}$ & Z-score & p-value \\
\hline (ii) mass & $96 \%$ & $93 \%$ & $-0,707$ & 0,480 & $30 \%$ & $26 \%$ & $-0,504$ & 0,614 \\
\hline (iii) neg sg & $98 \%$ & $100 \%$ & $-1,000$ & 0,317 & $25 \%$ & $19 \%$ & $-0,722$ & 0,470 \\
\hline (iv) non-ref. & $75 \%$ & $88 \%$ & $-1,588$ & 0,112 & $44 \%$ & $37 \%$ & $-0,924$ & 0,356 \\
\hline (v) neg pl & $82 \%$ & $95 \%$ & $-1,265$ & 0,206 & $37 \%$ & $51 \%$ & $-1,456$ & 0,145 \\
\hline (vii) refer. & $91 \%$ & $88 \%$ & $-0,535$ & 0,593 & $26 \%$ & $33 \%$ & $-1,190$ & 0,234 \\
\hline (viii) def + adj & $86 \%$ & $98 \%$ & $-1,933$ & 0,053 & $32 \%$ & & & \\
\hline
\end{tabular}


Table 7 shows that, in the correct sentences, there are no significant differences between French L2 and German L1. The result for context (viii), with a definite article + adjective, shows a marginally non-significant difference. In the incorrect sentences, there are no significant differences either.

Whether these results support one of the hypotheses formulated in Section 4.1 is discussed in the next section.

\section{Discussion}

In this study, we are testing three hypotheses based on the fact that German, in contrast to French, does not have a partitive pronoun (Section 4.1). According to Hypothesis 1, German L1 speakers learning French as their L2 will differ significantly from L1 French speakers, both in contexts where en is required in French and in contexts where en is not used, or they will perform at chance. According to Hypothesis 2, the French L2 learners will differ significantly from the native speakers of French in contexts where en is required in French but not in contexts where en is not used. Finally, according to Hypothesis 3, there may be positive influence from L1 German in contexts in which L1 German and L1 French have similar constructions and negative influence in contexts in which these languages differ.

For Hypothesis 1 to be supported, there should be significant differences between French L1 and French L2 in all the contexts studied here, namely contexts (i)-(viii) described in Section 2.1, or the learners should perform at chance. As seen in the discussion of Figures 3 and 4 and Table 6 in the previous section, this is not the case. For correct sentences, only two out of the eight contexts show significant differences between French L1 and French L2 speakers: context (i) with a quantifier and context (vi) with an indefinite article + adjective. In four contexts, the differences are not significant: (ii) with a mass noun, (iii) with a negated singular indefinite, (v) with a negated plural indefinite and (vii) with a referential plural indefinite. As for contexts (iv) and (viii) with, respectively, a non-referential plural indefinite and a definite article + adjective, the results are marginally significant. Even if the latter are interpreted as significant, since they are at the limit of 0,05 , only half of the contexts show significant differences between French L1 and French L2. In addition, in the contexts without significant differences, the learners do not perform at chance, as they accept the sentences in at least $82 \%$ of the cases. This rather shows a "mastering" level. In the contexts with a significant difference, the percentages are also above chance (assuming that at chance means 50\%): in context (i) with a quantifier, the items are accepted 
in $77 \%$ of the cases, in context (iv) with a non-referential plural indefinite in $75 \%$ of the cases, and in context (vi) with an indefinite article + adjective in $56 \%$ of the cases. All the above elements show that Hypothesis 1 is not confirmed for the correct sentences.

Regarding the incorrect sentences, there are significant differences in six contexts, namely (i), (ii), (iii), (v), (vi), and (viii); however, we also find two exceptions, namely contexts (iv) with a non-referential plural indefinite and (vii) with a referential plural indefinite, which falsifies Hypothesis 1. Furthermore, in most of the contexts the learners perform above chance. This confirms that this hypothesis has to be rejected.

To evaluate Hypothesis 2, the contexts in which en is required, i.e. (i)-(vi), and the ones in which en is impossible, i.e. (vii)-(viii), have to be distinguished: if this hypothesis is correct, there should be significant differences between French L1 and French L2 only in the former contexts, not in the latter. For correct sentences, two significant differences for French L1 and French L2 concern contexts in which en is required: (i) with a quantifier and (vi) with an indefinite article + adjective. In addition, one context is marginally significant, context (iv) with non-referential plural indefinites. However, there are also two contexts requiring en with no significant differences, that is, (ii) with a mass noun, (iii) with a negated singular indefinite, and ( $v$ ) with a negated plural indefinite. In other words, not all of the contexts requiring en, (i)-(vi), show significant differences between French 1 and French L2. As for contexts (vii) and (viii), there is a non-significant difference for context (vii), as predicted, but the difference for context (viii) is marginally significant.

For incorrect sentences, there is a significant difference for all the contexts in which en is required, except for context (iv) with a non-referential plural indefinite. In addition, there is a significant difference for one of the two contexts in which en is impossible, namely (viii) with a definite article + adjective. The fact that there is one non-significant difference among the contexts in which en is required and one significant difference among the contexts in which en is impossible is problematic for Hypothesis 2. On the basis of both the correct and the incorrect sentences, our results therefore prevent us from concluding that this hypothesis is correct.

Let us now turn to Hypothesis 3 and see if it fares better. To evaluate this hypothesis, we need to examine, on the one hand, the contexts that are similar in German and French, and, on the other hand, the ones that are different. We saw in the previous section that contexts (i) and (vi) are not similar in the two languages because German does not have an overt counterpart to en in these contexts. As for the other contexts, the comparison between French L1 and German L1 confirms that they can be considered alike in the two languages. Indeed, according to 
Figure 1 for correct sentences, there were no significant differences for the contexts (ii)-(v) and (vii)-(viii) and the participants accepted the examples in at least $88 \%$ of the cases (cf. Table 5).

To determine whether there is transfer from the L1 (see Section 3.1), we will focus first on the comparison between German L1 and French L2 (cf. Section 5.3). If there is positive transfer from L1, there should be no significant differences in the contexts that are similar in the two languages (i.e. (ii)-(v) and (vii)-(viii)). Since we have no statistical results for contexts (i) and (vi), we cannot establish if there is possible negative transfer on the basis of the comparison between German L1 and French L2.

For correct sentences, none of the results in contexts (ii)-(v) and (vii)-(viii) show significant differences, apart from the result for context (viii) with a definite article + adjective, i.e. $p=0,053$, which is marginally significant (cf. Table 7). This can be explained as follows: in contexts (ii)-(v), en is used in French where German has welch, in context (vii) with a referential plural indefinite, French has a definite pronoun like German, and in context (viii) with a definite article + adjective, it has no pronoun, like German, since en is ungrammatical. The results therefore suggest positive transfer from the L1 in contexts (ii)-(v) and (vii)-(viii). For our study, what is particularly interesting is that the use of welch in the German contexts (ii)-(v) seems to facilitate the learning of en in those contexts. For the incorrect sentences, there were no significant differences either for contexts (ii)-(v) and (vii), which strengthens our conclusion on positive transfer. As for context (viii) with a definite article + adjective, we did not have any ungrammatical test items, just as for contexts (i) with a quantifier and (vi) with an indefinite article + adjective.

After having established on the basis of the comparison between German L1 and French L2 that there may be at least positive influence from German L1, we evaluate Hypothesis 3 by looking again at the comparison between French L1 and French L2. If there is positive transfer from L1, there should be no significant differences in the contexts that are similar in the two languages (i.e. (ii)-(v) and (vii)-(viii)). If there is negative transfer, there should be significant differences in the contexts that are different (i.e. (i) and (vi)).

We first look at the contexts (i) and (vi). In contexts (i), with a quantifier, and (vi), with an indefinite article + adjective, the L2 learners differed significantly from the native speakers of French, both in correct and incorrect sentences, see Table 6. Since these constructions are different in the two languages, this suggests that there is negative transfer from the L1 German. In other words, the absence of a pronoun (i.e. welch) in these two contexts in German, in contrast to French which has en in these constructions, negatively influenced the students in their learning process. The fact that contexts (i) and (vi) are the only ones for which there are clearly significant differences in both types of sentences (correct and incorrect) strengthens this conclusion. 
If there is positive transfer, there should be non-significant differences between French L1 and L2 in contexts (ii)-(v) and (vii)-(viii). For the "similar" contexts, we found a non-significant difference for context (vii), with referential plural indefinites, as expected, both in the correct and in the incorrect sentences. Both German L1 and French L1 use a definite pronoun in this context. Within some other "similar" categories, namely contexts (ii) with a mass noun, (iii) with a negated singular indefinite, and (v) with a negated plural indefinite, in which German uses welch and French en, we found a non-significant difference for the correct sentences, as expected, but a significant difference for the incorrect sentences, in which the definite pronoun was used instead of en. This result can be explained if we consider that in the L1 German results the definite pronoun was also accepted to some degree in these contexts. We did not find a significant difference for context (iv) with non-referential plural indefinites between French L1 and French L2 in the incorrect sentences, but this can be explained by the surprisingly high acceptance of the definite pronoun in L1 French in this context. In the correct non-referential plural context, there was a slightly significant, nonexpected, difference between French L1 and L2. Because of their resemblance to the referential contexts, the non-referential contexts were difficult to judge, especially for the L2 learners. For the "similar" context (viii), definite article + adjective, we found an unexpected significant difference in the incorrect sentences, which was, however, counterbalanced by an only marginally significant difference difference in the "correct" counterpart.

Although some explanations that we have given for the results may also be used to strengthen Hypothesis 2 (or Hypothesis 1), the difference between Hypothesis 2 and Hypothesis 3 is that with Hypothesis 3 we can attribute the significant differences in the incorrect contexts, i.e. contexts (ii) with mass nouns, (iii) with negated singular indefinites, and (v) with negated plural indefinites, to the acceptance of the definite pronoun in welch contexts in German L1.

In conclusion, our discussion shows that Hypothesis 3 is borne out: there is clear positive transfer in the constructions that are similar in both languages, and negative transfer in the ones in which they differ. This means that the existence of an element like welch in German, which is similar to en in some aspects (although also different in others), helps the L2 speakers in their learning of the uses of en. A similar conclusion is drawn by Berends et al. (2021, this volume) for the L2 acquisition of the Dutch partitive pronoun er by L1 English and French learners. 


\section{Conclusion}

The analysis of possible transfer strategies from a language that does not have a partitive pronoun, German, to a language that has one, French, has enabled us to sharpen our insight into the notion of transfer. While keeping the traditional distinction between positive transfer based on similarities and negative transfer based on differences, we have argued that there may be positive transfer even if German does not have a partitive pronoun, and that this positive transfer does not only concern constructions in which French does not use en (no pronoun or a definite pronoun), but also constructions in which German uses the indefinite anaphoric pronoun welch.

The distinction between non-referential NPs and referential NPs was not easy to make in both languages. It may be that this was caused by the design of our test sentences, which in a future study could be improved.

\section{References}

Badía i Margarit, Antoni M. 1947. Les complements pronominals-adverbials derivades de ibi $e$ inde en la peninsula iberica, Madrid. Consejo Superior de Investigaciones Científicas (Revista de Filología Española, Annex XXXVIII).

Badía i Margarit, Antoni M. 1951. Gramática histórica catalana. Barcelona: Noguer.

Bech, Gunnar. 1952. Über das niederländische Adverbialpronomen er. Kopenhagen: Nordisk Sprog- of Kulturforlag [etc]. Travaux du Cercle Linguistique de Copenhague 8.

Belletti, Adriana, Elisa Bennati \& Antonella Sorace. 2007. Theoretical and developmental issues in the syntax of subjects: Evidence from near-native Italian. Natural Language and Linguistic Theory 25. 657-689.

Berends, Sanne, Petra Sleeman, Aafke Hulk \& Jeannette Schaeffer. 2021, this volume. The L2 acquisition of the referential semantics of Dutch partitive pronoun ER. In Petra Sleeman \& Giuliana Giusti (eds.), Partitive determiners, partitive pronouns and partitive case (Linguistische Arbeiten 580). Berlin: De Gruyter.

Fukui, Naoki. 1995. The Principles and Parameters approach: A comparative syntax of English and Japanese. In Masayoshi Shibatani \& Theodora Bynon (eds.), Approaches to language typology, 327-372. Oxford: Clarendon Press.

Gerards, David Paul. 2020. Bare partitives in Old Spanish and Old Portuguese. University of Zurich dissertation.

Giusti, Giuliana. 2021, this volume. Partitivity in Italian. In Petra Sleeman \& Giuliana Giusti (eds.), Partitive determiners, partitive pronouns and partitive case (Linguistische Arbeiten 580). Berlin: De Gruyter.

Giusti, Giuliana \& Petra Sleeman. 2021, this volume. Partitive elements in the languages of Europe. An advancement in the understanding of a multifaceted phenomenon. In Petra Sleeman \& Giuliana Giusti (eds.), Partitive determiners, partitive pronouns and partitive case (Linguistische Arbeiten 580). Berlin: De Gruyter. 
Glaser, Elvira. 1992. Umbau partitiver Strukturen in der Geschichte des Deutschen. Sprachwissenschaft 17(2). 113-132.

Glaser, Elvira. 1993. Syntaktische Strategien zum Ausdruck von Indefinitheit und Partitivität im Deutschen (Standardsprache und Dialekt). In Werner Abraham \& Josef Bayer (eds.), Dialektsyntax, 99-116. Opladen: Westdeutscher Verlag.

Glaser, Elvira. 2008. Syntaktische Raumbilder. In Peter Ernst \& Franz Patocka (eds.), Dialektgeographie der Zukunft, 85-111. Stuttgart: Steiner.

Hermas, Abdelkader. 2010. Language acquisition as computational resetting: Verb movement in L3 initial state. International Journal of Multilingualism 7. 343-362.

Ihsane, Tabea. 2013. EN pronominalisation in French and the structure of nominal expressions. Syntax 16(3). 217-249.

Jin, Fufen. 2009. Third language acquisition of Norwegian objects: Interlanguage transfer or L1 influence? In Yan-kit Ingrid Leung (ed.), Third language acquisition and Universal Grammar, 44-161. Clevedon: Multilingual Matters.

Kaku, Keiko. 2006. Second language learners' use of English articles: A case study of native speakers of Japanese. Ottawa Papers in Linguistics 34. 63-74.

Kampen, Jacqueline van \& Manuela Pinto. 2007. Germanic and Romance discourse devices in acquisition. In Sergio Baauw, Jacqueline van Kampen \& Manuela Pinto (eds.), The acquisition of Romance languages: Selected papers of the Romance Turn II 2006. LOT Occasional series 8, 73-96. Utrecht: LOT.

Lado, Robert. 1957. Linguistics across cultures. Ann Arbor: University of Michigan Press.

Martins, Ana Maria. 2014. Syntactic change in Portuguese and Spanish: divergent and parallel patterns of linguistic splitting. In Patrícia Amaral \& Ana Maria Carvalho (eds.), Portuguese-Spanish interfaces: Diachrony, synchrony, and contact, 35-64. Amsterdam: John Benjamins.

Master, Peter. 1987. A cross-linguistic interlanguage analysis of the acquisition of the English article system. Los Angeles: University of California dissertation.

Milner, Jean-Claude. 1978. De la syntaxe à l'interprétation: quantités, insultes, exclamations. Paris: Seuil.

Montrul, Silvina \& Celeste Rodríguez Louro. 2006. Beyond the syntax of the Null Subject Parameter: A look at the discourse-pragmatic distribution of null and overt subjects by L2 learners of Spanish. In Linda Escobar \& Vincent Torrens (eds.), The acquisition of syntax in Romance languages, 400-418. Amsterdam: John Benjamins.

Na Ranong, Sirirat \& Yan-kit Ingrid Leung. 2009. Null objects in L1 Thai-L2 English-L3 Chinese: An empiricist take on a theoretical problem. In Yan-kit Ingrid Leung (ed.), Third language acquisition and Universal Grammar, 162-191. Clevedon: Multilingual Matters.

Odlin, Terence. 1989. Language transfer: Cross-linguistic influence in language learning. Cambridge: Cambridge University Press.

Philippa, Marlies, Frans Debrabandere \& Arend Quak. 2004. Etymologisch handboek van het Nederlands, part 1, A-Ezelsbrug. Amsterdam: Amsterdam University Press.

Pienemann, Manfred, Bruno Di Biase, Satomi Kawaguchi \& Gisela Håkansson. 2005. Processing constraints on L1 transfer. In Judith Kroll \& Annette de Groot (eds.), Handbook of bilingualism. Psycholinguistic approaches, 128-153. Oxford: Oxford University Press.

Pinto, Manuela. 2018. L'italiano L2 e le regole che non si insegnano a scuola. Incontri 33(1). 42-55. www.rivista-incontri.nl/articles/abstract/10.18352/incontri.10234

Rothman, Jason. 2007. Pragmatic solutions for syntactic problems: Understanding some L2 syntactic errors in terms of discourse-pragmatic deficits. In Sergio Baauw, Frank 
Drijkoningen \& Manuela Pinto (eds.), Romance languages and linguistic theory 2005, 299-320. Amsterdam: John Benjamins.

Schwartz, Bonnie \& Rex Sprouse. 1994. Word order and nominative case in non-native language acquisition: a longitudinal study of (L1 Turkish) German interlanguage. In Teun Hoekstra \& Bonnie D. Schwartz (eds.), Language acquisition studies in generative grammar, 317-368. Amsterdam: John Benjamins.

Schwartz, Bonnie \& Rex Sprouse. 1996. L2 cognitive states and the full transfer/full access model. Second Language Research 12. 40-72.

Sleeman, Petra \& Giuliana Giusti (eds.). 2021, this volume. Partitive determiners, partitive pronouns and partitive case (Linguistische Arbeiten 580). Berlin: De Gruyter.

Sleeman, Petra \& Tabea Ihsane. 2017. The L2 acquisition of the French quantitative pronoun en by L1 learners of Dutch. Vulnerable domains and cross-linguistic influence. In Elma Blom, Jeannette Schaeffer \& Leonie Cornips (eds.), Cross-linguistic influence of bilingualism. In honor of Aafke Hulk, 303-330. Amsterdam: John Benjamins.

Sleeman, Petra \& Tabea Ihsane. 2020. Convergence and divergence in the expression of partitivity in French, Dutch, and German. Linguistics 58(3). 767-804.

Stadt, Rosalinde, Aafke Hulk \& Petra Sleeman. 2018. The influence of L1 Dutch and L2 English on L3 French: A longitudinal study. Journal of the European Second Language Association 2(1). 63-71. DOI: http://doi.org/10.22599/jesla.42.

Strobel, Thomas. 2016. Die syntaktische Variable 'pronominale Partitivität' in den Deutschen Dialekten. In Alexandra N. Lenz \& Franz Patocka (eds.), Syntaktische Variation: Areallinguistische Perspektiven, 151-197. Vienna: Wiener Arbeiten zur Linguistik.

Strobel, Thomas. 2017. Pronominale Partitivität. Arealität und Mikrovariation einer morphosyntaktischen Variable in den Varietäten des Deutschen. Frankfurt: Goethe University dissertation.

Wust, Valerie. 2009. A la recherche des clitiques perdus: The dictogloss as a measure of the comprehension of $y$ and en by L2 learners of French. The Canadian Modern Language Review 65(3). 471-499.

Zobl, Helmut. 1984. Cross-language generalizations and the contrastive dimension of the interlanguage hypothesis. In Alan Davies, Clive Criper \& Anthony P.R. Howatt (eds.), Interlanguage, 79-97. Edinburgh: Edinburgh University Press. 